\title{
Challenges Facing Adult Educators and Community Development Practitioners in Curbing the Dangers of Youth Restiveness in the Niger Delta
}

\author{
Dr. Esuefieni J. Etigbamo \\ Dept of Foundations Studies, Isaac Jasper Boro College of Education, Sagbama Town, Bayelsa State \\ Email: esueet@yahoo.com \\ Dr. Apuega R. Arikawei \\ Department of Educational Foundations, Niger Delta University, Wilberforce Island, Bayelsa State \\ Email: arikawei@gmail.com
}

\section{Doi:10.5901/jesr.2014.v4n6p243}

\section{Abstract}

The Niger Delta region of Nigeria have been very turbulent and unstable in the past few years .Cases of kidnapping and hostage taking of oil and gas company workers including top government officials and members of their families has been in the increase. Pipeline vandalism, local oil refining, sea piracy, looting, mismanagement and wastage of state resources have become a near normal phenomenon. The region has experienced a state of near anarchy at one time or the other as lives and prosperities worth billions of naira were destroyed. The restiveness is attributed to the neglect and marginalization of the region by the federal government of Nigeria despite the regions' contribution of over $90 \%$ of the nation's foreign exchange earnings through the crude oil reserves in the area. Various measures such as the establishment of OMPADEC, NDDC and the peace and conflict resolution committee have been proffered but the solution to these endemic challenges remains a far cry especially as the area still remains one of the least development region in the country. This paper x-rays the dangers posed by youth restiveness in the Niger Delta region. It dwelt on the challenges faced by adult educator and community development practitioners in addressing these problems towards maintaining peace to accelerating development in the region.

Keywords: Oil Companies, Crude oil, Pollution, Region, Violent Crimes, Training, Leaders

\section{Introduction}

Adult Education and Community Development are two field of endeavour that are complementary in nature as both are geared toward the emancipation of people, society and nation from the shackle of poverty, ignorance, disease and illiteracy. The adult educators and community development practitioners have a significant role to play in the achievement of sustainable development of any society.

According to Nzeneri (1996) an adult educator is a person who consciously and systematically administers the teaching learning activities, programmes and processes with the primary aim of assisting others to learn (i.e. attain their desire learning goals). On the other hand a community development practitioner for the purpose of this study can be seen as a specialist, a facilitator, a motivator, an organizer or a change agent who assist in helping communities to develop through self-help or external assistance from government, corporate organizations, and Non-governmental organizations (NGOs). Therefore, the place of Adult education and community development cannot be underestimated in the development of the Nigerian society.

\section{Characteristics of Adult Educators and Community Development Practitioners}

The adult educator and community development practitioner possess some unique qualities which are similar in their mode of practice. According to Nzeneri (1996) an adult educator should posses the following qualities.

- The Adult educator is expected to inspire in the learner to learn. He should be able to motivate and raise learners' consciousness and enthusiasm to learn.

- Identify individual differences among learners. Learners have differences in term of age, sex, background, socio-economic and political status. The adult educator should take these into account and should be able to 
control them so as to create a sense of common group loyalty which is very crucial for adult teaching and learning environment.

- Exhibit tolerance: The adult educator should recognize adult learning group as heterogeneous groups. He is expected to be patient, kind, sympathetic and flexible so as to encourage effective participation of learners in their learning task.

- Good personality: For adult educator to have good personality, he should be knowledgeable, versatile, communicate effectively with learners, have a cordial relationship with others and should be impartial in dealing with learners.

- Be resourceful: This is very important attribute of adult educators since they are expected to be managers and administer the scarce human and non-human resources. As resourceful persons, the adult educator should know how to manage and improve all learning and teaching situations through effective control mechanism.

- Understanding and Awareness: The adult educator should properly understand learner's educational needs, interest and aspirations; he should be aware of learners' priority or problems and difficulties and should adopt suitable methods/techniques to solve them.

In similar vein, the community development practitioners share most of the qualities of an adult educator. However, as a leader and change agent, a community development practitioner exhibits some other characteristics which Osuji (1991) enumerated as good communication skills, command respect, humility, simple, knowledgeable, good physical appearance, courage, empathy, visionary and diplomacy which is needed to bring about changes in any given society.

\section{Functions of Adult Educators and Community Development Practitioners}

The adult educators and community development practitioners in the performance of their duties exhibited similar functions which are geared toward improving human lives. Zuofa (2004) summarized some of the general functions carried out by the adult educators and community development practitioners to include:

- As an expert in the control and management of resource;

- As a guidance counsellor;

- As a planner of community projects and programmes;

- As an organizer of activities to uplift human living;

- As a mobilize with leadership roles;

- As a modeler; and

- As a motivational speaker who carries everybody along in community issues.

Apart from the above functions, the adult educator and community development practitioner are saddled with the responsibility of promoting education through service delivery at the community level. It is their place to ensure that potential learners such as the out-of-school, the adults, women and youths are mobilized to access education. The education could be in the form of vocational and skills acquisition needed for the capacity building of the recipient for personal self and societal development.

\section{The Niger Delta Region of Nigeria}

The Niger Delta region of Nigeria is located in the Southern part of the country. It is been described as a fan-shaped feature that extends to about 70,000 square kilometers and the third largest delta in the world, Peterside (2011). According to Iwena (2000), the region is generally a lowland area of about $0.30 \mathrm{~m}$ above the sea-level. The area consists mainly of muddy deposits formed where the Niger River flows into a relatively tide less sea and the rock is mainly sedimentary while the soil type is the alluvial. The climatic type is the sub-equatorial climate while the vegetation is mainly that of the mangrove swamp forest.

The definition of the Niger Delta region consist of nine (9) states to include Abia, Imo, Edo, Ondo, Akwa Ibom, Bayelsa, Cross Rivers, Delta and Rivers State. Meanwhile, Ibaba (2005) reported that the widespread view of the Willink Commission sees the Niger Delta region as the south-south geo-political zone made up of Akwa Ibom, Bayelsa, Cross Rivers, Delta, Edo and Rivers State ( with Akwa Ibom, Bayelsa, Delta and Rivers State classified as the core Niger Delta States). The region is inhabited with over twenty million people of more than forty (40) ethnic groups speaking some 250 dialects, while their livelihood is primarily derived from fishing and farming, Efik (2011). 
According to Owede (2005) the Rivers State leaders of thought defined the people of the Niger Delta to include;

i. ljaws of western division

ii. ljaws of Brass division

iii. ljaws of Degema division

iv. Ogonis and Elemes of Ogoni division

v. Ikwerres and other tribes in Port Harcourt

vi. Etches, Ekpeyes, Ogbas, Egbemas

vii. Engennis and Abuas of Ahoada division

viii. Obolos and Opobians of Opobo division

In addition, there are the Isokos, Urhobos, Itsekiris and Kwale from the western axis while the Eastern parts consist of the Oron, Ibibios, Anang, Effiks etc of Akwa Ibom and Cross Rivers State.

Azaiki (2003) classified the occupations of the people of the Niger Delta into primary, secondary and tertiary. The primary occupations are farming and fishing while the secondary are local industries including trade, commerce and transport. The Niger Delta people share a common destiny in that they have similar historical and economic problems. Despite the hostile terrain, the region is blessed with agriculture, cash crops and crude oil which are the economic mainstay of Nigeria.

According to Ashton-Jones, Arnott and Douglas (1998) oil reserves from the Niger Delta provides about $25 \%$ of gross domestic product (GDP), $90 \%$ of foreign exchange earnings and $70 \%$ of budgetary expenditure in Nigeria. The exploration of oil in the Niger Delta is viewed by many as a curse rather than being a blessing and a means of development in the area. This is manifested as the region being the goose that is laying the golden egg is not given much attention and well taken care of but rather neglected and abandoned by successive Nigerian governments. This has led to many struggles for self-determination and resource control. Asuka (2010) highlighted that the agitators included the 21 days revolution by Isaac Adaka Boro, the Ogoni struggle led by Ken Saro Wiwa and the Kaiama Declaration whose intention was to make known to the whole world the injustice and economic backwardness suffered by the people of ljaws and the Niger Delta.

\section{Youth Restiveness in the Niger Delta}

A youth is defined in different ways depending on the objectives and realities of the given society. In Nigeria, a youth is described as all young persons of ages 18-35 years who represent the most active, volatile and vulnerable segment of the population, Federal Republic of Nigeria (FRN,2001). Due to the nature of their vulnerability, some youth display great aspirations and un-met needs. In Nigeria, many youths are faced with the challenges of poor education, cult activities and breakdown of family values. The inability for some of the youth to cope with some of these vice resigned them to hopelessness and restive.

The Oxford Advanced Learners Dictionary defined restive as unable to stay or unwilling to be controlled, especially because you feel bored or not satisfied. In the Niger Delta, restiveness of youth has become a common feature posing lots of threat to the economic survival of the nation. This is so as the nation depend largely on crude oil found in the region for its sustenance. In the views Akiri (2006), he submitted that the Niger Delta presents the greatest and gravest challenge to the contemporary stability of Africa's most populous State.

According to Gab (2005) the struggle in the Niger Delta is a reaction to the root of national discomfort in what continues to manifest in the form of corruption, insecurity and poverty. The Niger Delta region where much of the nation wealth comes from has absolutely nothing to show for the long years of predatory oil exploration and exploitation by multinational oil firm.

Communities of the oil rich Niger Delta are left with sad tell-tale and signs of absolute environmental degradation and utter neglect from Edo to Delta, Bayelsa to Rivers, Akwa-lbom and Cross River State. The region is characterized with bad roads, high unemployment, low life span, infrastructural decay, female prostitution, high illiteracy, low industrialization rate and environmental pollution. Genuine struggle for development of the region has often been suppressed by the powerful hands of government.

Over the years, anger started building up in the youth as a dynamic mechanism of humans as Martin Luther king (Jr) pointed out that fear can suppress anger, while anger can produce the courage that overcomes fear. From the days of Isaac Adaka Boro till the time of Kenule Saro-Wiwa, there has been so much social pressure against the expression of anger. It was such expression of anger without due attention from the authorities that leads to helplessness of the people to overcome their fears. 
As the people of the Niger Delta continue to struggle against depression, helplessness and hopelessness orchestrated by neglect from government and multinational companies, it beats their imagination to watch in the television day after day the opulence of edifice in areas not endowed in term of oil and gas. From behind the ghetto walls, they see glistering towers of glass and steel building spring up almost overnight.

As a result, youths in the Niger Delta region looked up to late Ken Saro Wiwa and other hero's of the region who laboured courageously with great sacrifice to agitate for equity for the region. With sheer determination to demand from government for resource control, some of the youths were arrested and jailed while others were killed in the process. According to Torutein (2008) Niger Delta youths took to the bushes in different dimension because they felt the road to justice in Nigeria does not exist or at best leads to nowhere. Thus different militia groups sprang up over-night, all claiming to be freedom fighters. But because their anger was not harnessed through constructive means, it became diverted into desperate and anti-human activities. Hence they are tagged and called restive youths in various quarters.

\section{Causes of Youths Restiveness in the Niger Delta Region}

The manifestation of youth restiveness in the Niger Delta has been attributed to several factors. Ogon (2007) asserted that conflict in the Niger Delta which has resulted to youth militancy, is embedded in a triangular relationship between the government, oil and gas companies and communities where resources are exploited. In appraising the scenario, Torutein (2008) highlighted that violent and youth restiveness in the Niger Delta is caused by the following:

- Injustice by federal government through her policies as represented in the land use act of 1978, petroleum act of 1969, decree 15 of 1967, decree 13 of 1970, decree 38 of 1971 and decree 6 of 1975. These obnoxious laws according to him are the sources of deprivation and marginalization of the Niger Delta region resulting to series of agitations.

- Unemployment: most of the employable youths are not employed and so they are found to be engaged in anything including robbery, kidnapping and sea piracy to eke out a living.

- Lack of social amenities: This is one major cause of violent and youth restiveness in the Niger Delta region. The federal government presence is not adequately felt since the discovery of oil in the region. There is no pipe borne water, no electricity and absence of adequate hospitals. The people of the Niger Delta region especially those in the rural communities drinks from the river water which has been polluted by oil exploration. Hence cases of water-borne disease abound.

- Non-implementation of memoranda of understanding entered into between oil companies and communities. Government in most cases serves as witness through her agencies, but turn out to rather over protect the oil companies to the detriment of the host communities.

Apart from the above, other causes of youth restiveness and violent in the Niger Delta region is pollution and ecological degradation occasioned by the exploration and production activities of oil companies. Ekpenyong (2006) noted that since 1956 when oil was first discovered at Oloibiri in Ogbia local government area of Bayelsa State, the community, and indeed the entire Niger Delta region have been exposed to several forms of environmental abuses. He maintained that oil spillage, gas flaring and all other forms of environmental disaster constitute serious environmental hazards particularly to the flora and fauna of the area.

Similarly Owede (2005) pointed out that one major problem is the psychological depression resulting from the source of livelihood owing to the loss of fertility of the soil and pollution of rivers. The activities of oil companies have reduce the yield of the land and rivers. In fact, the people's means of livelihood have been jeopardized especially with the pollution of their primary economic occupation as farmers and fishermen.

Illiteracy, poverty and diseases are some of the causes of violent and youth restiveness in the Niger Delta region. An illiterate, ignorant and hungry man is a danger to the society. The Niger Delta region is characterized with bad roads, poverty, and high rate of illiteracy, diseases, low industrialization and untimely death. Hence Okoko (2005) noted that the people of the region are push to the wall with no alternative but to fight back. These varied forms of reaction of the people are always termed violence and restive by government.

\section{Effects of Youth Restiveness in the Niger Delta}

The effect of youth restiveness does not only impact on the Niger delta region but the national and global scenes. Some of the negative vices resulting from the restiveness of youths are outlined by Owede (2005) and Ikuli (2012) to include: 
- Insecurity: youth restiveness has caused a state of insecurity in the Niger Delta region especially Rivers, Delta and Bayelsa State. No one is sure of what will happen in the next minute. Lawlessness is now becoming a norm and people leaves in fear of the unknown. In addition, soldiers have eventually taken over the region causing fear and intimidation to inhabitants of the area.

- Economic stagnation: Investors are scare of the insecurity situation in the region. The region is seen as a "No Go Area". This has led to economic stagnation as investors would only invest in peaceful and restive free areas.

- Diversion of attention and fund at the expense of rural communities. The government, oil firms and other companies have diverted their attention and fund to security agencies for the protection of their lives and installations instead of developing the region. It is a known fact that both oil firms and construction companies spent a lot of fund to keep soldiers around their working sites. Government also spent so much money as ransom on hostage taking. These funds would be better spent on education, health care, agriculture, construction of roads, provision of houses and potable drinking water as permanent solution to some of these problems.

- Pollution of the environment: When oil installations are attacked and pipelines vandalized, crude oil is released to the environment, thereby causing serious environmental problems.

- Increase crime rate: Restiveness and violence leads to lawlessness where the rights of people are denied. The immediate financial benefit of hostage taking has made the youth to venture into other criminal activities such as cultism, thuggery, armed robbery, sea piracy and illegal bunkering.

- Underdevelopment and project abandonment: Violent and youth restiveness have led to loss of properties and destruction of social amenities which government and other organizations spend billion of naira to build. This consequently puts the region under perpetual underdevelopment. Development programmes embark upon by government and other organizations such as the defunct Oil Mineral Producing Area Development Commission (OMPADEC) and Niger Delta Development Commission (NDDC) are often abandoned as a result of youth restiveness. In fact, Ibaba (2012) noted that the construction of the East-West road (a major development project in the area) was halted by militia attacks on expatriate staff of Julius Berger, the company constructing the east-west road which resulted to a serious setback on the completion date of the project.

Apart from the above effect, government attention to the regions, observance of environmental safety standard e.g. environmental impact assessment (EIA), increased budgetary allocation are also subverted due to the endemic spate of restiveness in the region.

\section{The Challenges Facing Adult Educators and Community Development Practitioners}

The issue of youth restiveness no doubt, is one of the problems confronting the Nigerian society more than ever before. Apart from the insurgency of the recent boko haram, Akiri (2006) lamented that restiveness in the Niger Delta is the greatest challenge to contemporary stability of the country.

Adult educators and community development practitioners none the less, share from the cup of these challenges in the process of carrying out their mission. The following are some factors bedeviling their performances.

- Non functional State agencies for adult education. A critical survey of the various State agencies for adult education revealed that these agencies only exist in name. The lack of training centres seriously hampers the performance of their functions making their impact not to be felt.

- Another challenge facing adult educators and community development practitioners is the nonchalant attitude of government and oil firm toward adult educators and community development practitioners. These institutions seem not to be interested in the contributions of this profession to the solutions of youth restiveness. This neglect demoralizes practitioners from making useful suggestions and contributing their quota to the problems of youth restiveness in the region.

- Lack of adequate manpower is another great challenge facing adult educators and community development department as a professional field. This has consequently, affected the effective performance of the few professionals available in the field.

- Lack of fund: This is another challenge facing adult educators and community development practitioners in finding solutions to youth restiveness in the Niger Delta region. Government allocation to adult education agencies and community development department are rarely adequate to cater for their over head cost, not to 
talk of organizing workshop, seminar and embarking on enlightenment campaign on the negative effects of youth restiveness.

- Another challenge is the lack of basic infrastructure needed by practitioners to carry out their duties effectively. Most State adult education agencies lack even office space not to talk of equipment and material needed to combat the problems associated with youth restiveness.

- Lack of competent and visionary personnel as heads of agencies and literacy centres: operators of literacy programmes either as heads of agencies or literacy centres most times do not have the ability to plan and execute programmes that will have direct bearing to the solution of youth restiveness. As a result, some of these institutions exist only in names without the desired impact.

- Finally, non-availability of teaching and learning material in literacy centres: it is regrettable that literacy centres in the Niger Delta do not even have training materials needed for the education and re-orientation of ex-militant youths and school drop-outs especially in skills and knowledge acquisition in different areas of chosen profession. This ugly trend is bound to hamper the productivity level of adult educators and community development practitioners making their work a daunting challenge in the society.

\section{Recommendations}

In order to overcome the challenges of youth restiveness in the Niger Delta, the following recommendations are made:

i. Government should effectively finance the agencies for adult education and the department of community development in the local government councils. This will enable practitioners perform their duties effectively and contribute in reducing the menace of youth restiveness in the Niger Delta.

ii. The various states agencies for adult education and community development department should periodically organize workshop and seminars and plan programmes through campaigns and rallies to enlighten the youths on the effects of restiveness on the national economy.

iii. Professionals in the field of adult education and community development should be made head of agency for adult education and community development department respectively. This will help in making these parastatals more functional.

iv. Government should encourage scholars to venture into the field of adult education and community development. This can be done by providing scholarship for students in the field of adult education and community development to solving the problems of lack of manpower in the profession to reduce future challenges of youth restiveness in the Niger Delta region.

v. Practitioners in the field of adult education and community development should be encourage to organize themselves into an umbrella body to help champion their course and create the desired attention and awareness. This will create an avenue for practitioners to discuss and proffer solutions to the problem of youth restiveness in the Niger Delta.

vi. Finally government should create literacy and community development centers in the various local government areas in the Niger Delta region. This will provide practitioners an avenue to impact their knowledge, skills and experienced and invariably contribute to the problem of youth restiveness.

\section{Conclusion}

The dangers associated with youth restiveness in the Niger Delta poses a hydra-headed monster threatening the collective interest of the Nigerian state. In order to bring about a secured youth development as potential leaders of tomorrow in the Niger Delta, stakeholders including the government, oil firms, professionals, NGOs, community leaders and parents must wake up to their collective responsibility. Although, the restiveness of youths is attributed to the brainchild of long years of injustice, neglect and marginalization of the region, and could be eliminated when some of these issues are whole hearted addressed, the researchers however believes that the process will involve creating the right avenue for adult educators and community development practitioners to bring their experience to bear by inculcating genuine value and moral reorientation to the youths for national development. 


\section{References}

Akiri, A (2006): The Niger Delta problem and Nigerian Society: The Guardian Newspaper August 30

Ashton-Jones N, Arnott, S and Douglas O. (1998). The human ecosystem of the Niger Delta: Ibadan. Kraft books Ltd

Asuka, T.T. (2010): ljaw world-view and struggle for self-determination in the Niger Delta in Robert Ebizimor's song: Ibadan. StirlingHorden publishers Ltd

Azaiki, S. (2003): Inequalities in Nigerian Politics: Yenagoa. Treasure Communication Resources Ltd

Efik, S. (2011): Partnerships and capacities for the preservation of the Niger Delta Environment. In D. Peterside, M.Udeinya, D. Dakolo and N Onunwor (Ed.) Niger Delta environmental roundtable: A book of readings: Lagos: Prestige Publishing

Ekpenyong (2006): Environmental degradation in the Niger Delta region: Vanguard August 23

Federal Republic of Nigeria (2001): National youth policy: Abuja. Government Printing Press

Gab, A.E. (2005): Curbing youth restiveness in the Niger Delta: Vanguard May 21

Hornby, A.S. (2001). Oxford advanced learner's dictionary of current English, $6^{\text {th }}$ edition. New York. Oxford University Press

Ibaba, S.I (2005): Understanding the Niger Delta crisis. Revised edition: Port Harcourt. Amethyst and Colleagues Publishers

Ibaba, S.I (2012): Climate change and the risk of violent conflict in post-amnesty Niger Delta: Amassoma: Niger Delta University Publishers Ltd

Ikuli, W.O. (2012): Neo-ljawism and the journey so far: A tribute to Chief Olusegun Obasanjo: Abuja. Hank and whitney Ltd Iwena, O.A. (2005): Essentials geography for senior secondary schools: Lagos. Tonad Publisher Ltd

Nzeneri, I.S. (1996): Handbook on adult education: principal practices. Onitsha: Goodway Printing Press limited.

Ogon, P. (2007): Conflict management and peace building: Lagos. Unity Press Ltd

Okoko. K. (2005): Banner News Vol. 25 No 11 July 3-17 (p6)

Osuji, E.E. (1991): The nature of the community: Ibadan. Department of Adult Education: University of Ibadan.

Owede, K.E. (2005): Youth restiveness in the Niger Delta. An M.Ed Thesis: University of Port Harcourt. Unpublished

Peterside, D (2011): Introduction: overview of environmental problems of the Niger Delta. In D. Peterside, M.Udeinya, D. Dakolo and N Onunwor (Ed.) Niger Delta environmental roundtable: A book of readings: Lagos: Prestige Publishing

Torutein, D.O. (2008): The Effects of youth restiveness on community development in Bayelsa State. M.Ed Thesis: University of Port Harcourt. Unpublished

Zuofa, C.C (2004) Modern perspectives on adult education in Nigeria: Port Harcourt. Pre-Joe Publishers 
ISSN 2239-978X

ISSN 2240-0524
Journal of Educational and Social Research MCSER Publishing, Rome-Italy
Vol. 4 No. 6 September 2014 